\title{
Platelet Purinergic Receptors in Thrombosis and Inflammation
}

\author{
Christian Gachet $^{1} \quad$ Beatrice Hechler ${ }^{1}$ \\ ${ }^{1}$ Etablissement Français du Sang (EFS) Grand Est, Fédération de \\ Médecine Translationnelle de Strasbourg (FMTS), Université de \\ Strasbourg, Strasbourg Cedex, France \\ Hämostaseologie 2020;40:145-152.
}

\begin{abstract}
Address for correspondence Christian Gachet, MD, PhD, Etablissement Français du Sang-Grand Est, INSERM UMR_S1255, 10, rue Spielmann, BP 36, F-67065 Strasbourg Cedex, France (e-mail: christian.gachet@efs.sante.fr).
\end{abstract}

\begin{abstract}
Keywords

- nucleotides

- platelets

- thrombosis

- inflammation

- atherosclerosis

It took approximately 40 years from the seminal identification of adenosine diphosphate (ADP) as the factor $R$, an agent derived from red blood cells inducing platelet adhesion to glass, to the completion of the repertoire of its receptors on platelets and its importance in haemostasis and thrombosis. ADP, either derived from red blood cells or released by platelets themselves, stimulates platelets via two $G$ protein-coupled receptors, $P 2 Y_{1}$ and $P 2 Y_{12}$. In addition, adenosine triphosphate, also contained in the platelet dense granules, activates the $\mathrm{P} 2 \mathrm{X}_{1}$ cation channel. Each of these receptors plays a specific role during platelet activation and aggregation, with relevance to haemostasis, thrombosis and various inflammatory processes where platelets are involved including chronic responses such as atherosclerosis or acute responses such as sepsis, endotoxaemia or allergic asthma. Finally, platelets also express $\mathrm{P}_{2} \mathrm{Y}_{14}$, a receptor activated by released uridine diphosphate glucose. Although devoid of any known role in haemostasis, this receptor seems to play a specific role in neutrophil chemotaxis.
\end{abstract}

\section{Introduction}

Sixty years ago now, adenosine diphosphate (ADP) was identified as a factor released from erythrocytes which influenced platelet adhesiveness to glass ${ }^{1}$ and induced platelet aggregation. ${ }^{2}$ The crucial role of ADP as a mediator of platelet activation was rapidly recognized in the physiological process of haemostasis and in the development and extension of arterial thrombosis. ${ }^{3}$

ADP and adenosine triphosphate (ATP) are stored at a very high concentration in platelet dense granules and released upon activation of platelets by strong agonists such as thrombin and/or collagen. Released ADP is an essential secondary agonist, which amplifies most of the platelet responses and contributes to the stabilisation of the thrombus. ${ }^{4}$ Platelet stimulation by ADP leads to a transient increase in free cytoplasmic $\mathrm{Ca}^{2+}$ and inhibition of adenylyl cyclase activity. In addition, ATP induces an extremely rapid influx of
$\mathrm{Ca}^{2+}$ from the extracellular medium associated to platelet shape change. We know for years now that three different P2 receptors mediate these effects of adenine nucleotides on platelets: two $G$ protein-coupled receptors stimulated by $\mathrm{ADP}, \mathrm{P}_{2} \mathrm{Y}_{1}$ and $\mathrm{P} 2 \mathrm{Y}_{12}$, and the $\mathrm{P} 2 \mathrm{X}_{1}$ cation channel activated by ATP. Each of these receptors plays a specific role during platelet activation and aggregation, with relevance to haemostasis, thrombosis and various inflammatory processes where platelets are involved including chronic responses such as atherosclerosis or acute responses such as sepsis, endotoxaemia or allergic asthma. Platelets also express the $\mathrm{P}_{2} \mathrm{Y}_{14}$ receptor activated by uridine diphosphate (UDP) and UDP-glucose but its role, if any, remains elusive. ${ }^{5}$ The role of the $\mathrm{P} 2$ receptors in platelet activation, thrombus formation and inflammation has been presented and discussed in many reviews by us and by others that we cannot cite all for reasons of space. In this short overview, we will only briefly highlight several key points. received

November 12, 2019

accepted

January 23, 2020 (c) 2020 Georg Thieme Verlag KG Stuttgart · New York
DOI https://doi.org/ $10.1055 / \mathrm{a}-1113-0711$. ISSN 0720-9355. 


\section{The Platelet P2Y $_{1}$ Receptor}

The $\mathrm{P}_{2} \mathrm{Y}_{1}$ receptor is broadly expressed in many cells and tissues. Its presence and role in platelets were established by the detection of mRNA in megakaryoblastic cell lines and by pharmacological studies using selective $\mathrm{P}_{2} \mathrm{Y}_{1}$ antagonists. ${ }^{6} \mathrm{ADP}$ is the preferred natural agonist of the $\mathrm{P}_{2} \mathrm{Y}_{1}$ receptor, while ATP behaves as an antagonist in platelets ${ }^{7}$ or as a poor partial agonist in heterologous transfected or reconstituted systems, depending on the receptor density. ${ }^{8}$ The $\mathrm{P}_{2} \mathrm{Y}_{1}$ receptor is coupled to $\mathrm{Gq}$ and $\mathrm{Ca}^{2+}$ signalling. The changes in cytosolic $\mathrm{Ca}^{2+}$ concentration support the activation of the calcium and diacylglycerol-regulated guanine-nucleotide exchange factor 1 (CalDAG-GEFI), resulting in rapid and reversible activation of the small RAP1 GTPase and integrin $\alpha$ Ilb $\beta 3$, responsible for platelet shape change and weak and transient aggregation in response to $\mathrm{ADP}^{9}{ }^{9}$ Platelets express approximately $150 \mathrm{P}^{2} \mathrm{Y}_{1}$ receptors per cell, ${ }^{10}$ which is very low and probably explains why the signal induced by $\mathrm{P}_{2} \mathrm{Y}_{1}$ activation is weak as compared with the signals of other Gq-coupled receptors. To date, no $\mathrm{P}_{2} \mathrm{Y}_{1}$-deficient patients have been identified.

\section{The Platelet P2Y 12 Receptor}

The $\mathrm{P}_{2} \mathrm{Y}_{12}$ receptor, cloned in $2001,{ }^{11,12}$ is responsible for completion of the platelet aggregation initiated by the $\mathrm{P}_{2} \mathrm{Y}_{1}$ receptor in response to $\mathrm{ADP},{ }^{13}$ as well as for the role played by ADP in the amplification of aggregation, secretion and stabilisation of platelet aggregates induced by strong agonists such as thrombin, collagen or $\mathrm{TxA}_{2} \cdot{ }^{4,14}$ It is activated by ADP, while ATP and a wide range of its triphosphate analogues behave as antagonists. ${ }^{15}$ Platelets express approximately 400 copies of the $\mathrm{P}_{2} \mathrm{Y}_{12}$ receptor per cell. Owing its central role in the amplification of platelet responses to any stimulus, it is the molecular target of potent antiplatelet drugs including the thienopyridine compounds clopidogrel and prasugrel, which are prodrugs, and the direct antagonists ticagrelor and cangrelor. ${ }^{16,17}$ The tissue distribution of this receptor was long thought to be restricted to platelets and sub-regions of the brain. Further studies later revealed its expression and functions in microglial cells, vascular smooth muscle cells (VSMCs), dendritic cells (DCs), macrophages and as yet unspecified leukocytes and also bladder smooth muscle cells. ${ }^{18-20}$ In terms of signalling, the $\mathrm{P}_{2} \mathrm{Y}_{12}$ receptor activates a $G_{\alpha i 2} G$-protein subtype, responsible for the activation of two phosphoinositide 3-kinase (PI3-K) isoforms (PI3-K p110 $\beta$ and p110 gamma) that regulate $\alpha$ IIb $\beta 3$ activation via activation of the serine-threonine protein kinase $B / A k t$ (PKB/Akt) and the small GTPase RAP1 and the downward regulation of the RAP1 RAP-GAP RASA3 inhibitor. ${ }^{21,22} \mathrm{G}_{\alpha \mathrm{i} 2}$ also inhibits platelet adenylyl cyclase, which facilitates platelet activation.

Several patients have been identified with congenital $\mathrm{P}^{2} \mathrm{Y}_{12}$ receptor defects associated with quantitative or qualitative abnormalities of the receptor and responsible for deficiencies of ADP-induced platelet activation, leading to mild to severe bleeding diathesis which underscores the importance of this receptor in haemostasis. ${ }^{16,23}$

\section{The Platelet P2X Receptor}

The third member of the platelet $\mathrm{P} 2$ receptor panoply is the ligand-gated cation channel $\mathrm{P} 2 \mathrm{X}_{1}$, responsible for a fast $\mathrm{Ca}^{2+}$ entry induced by ATP. Pharmacological studies using specific $\mathrm{P} 2 \mathrm{X}_{1}$ ligands and $\mathrm{P} 2 \mathrm{X}_{1}{ }^{-1-}$ mice have shown that this receptor triggers transient shape change without causing platelet aggregation in response to $\mathrm{ATP}^{24}$ and participates in collagenand shear-induced aggregation. No $\mathrm{P} 2 \mathrm{X}_{1}$-deficient patients have been clearly identified to date. A mutation in the $\mathrm{P} 2 \mathrm{X}_{1}$ sequence has been reported in a patient with a severe bleeding disorder, but without firm demonstration of a causal link between the mutation and the bleeding tendency. ${ }^{25,26}$

\section{The Platelet P2 Receptors in Thrombosis}

So far, only the $\mathrm{P}_{2} \mathrm{Y}_{12}$ receptor is an established target for antithrombotic drugs in clinical use. The $\mathrm{P}_{2} \mathrm{Y}_{1}$ and $\mathrm{P} 2 \mathrm{X}_{1}$ receptors are also involved in experimental thrombosis and are at a preclinical stage of evaluation as potential targets for new antiplatelet agents.

\section{The Platelet P2Y $_{12}$ Receptor in Thrombosis}

The cornerstone of treatment of ischemic coronary syndromes is the dual antiplatelet therapy using aspirin and $\mathrm{P}_{2} \mathrm{Y}_{12}$ targeting drugs. ${ }^{17}$ Indeed, the central role of the $\mathrm{P}_{2} \mathrm{Y}_{12}$ receptor in platelet activation and the growth and stabilisation of a thrombus makes it a very important molecular target for antithrombotic agents. ${ }^{16,18}$ It is so far the only P2 receptor subtype to be an established target for antiplatelet drugs in clinical use and the major target to treat all kinds of arterial ischemic diseases. Active metabolites of the orally administered thienopyridine prodrugs (clopidogrel and prasugrel) covalently bind to the $\mathrm{P}_{2} \mathrm{Y}_{12}$ receptor while the direct-acting $\mathrm{P}_{2} \mathrm{Y}_{12}$ antagonists, ticagrelor, which is an oral antagonist, and cangrelor, an intravenous direct antagonist, reversibly bind the receptor and inhibit ADP binding. All these drugs are under clinical use for the treatment and prevention of thrombotic events in acute coronary syndromes. However, one limitation of targeting the $\mathrm{P}_{2} \mathrm{Y}_{12}$ receptor, whatever the drug, relates to the bleeding risk, which increases with the degree of inhibition of $\mathrm{P}_{2} \mathrm{Y}_{12}$-dependent platelet functions. ${ }^{27}$ The crystal structure of $\mathrm{P}_{2} \mathrm{Y}_{12}$ revealed how this receptor behaves when it binds agonists and antagonists. This should provide valuable insights into the development of improved $\mathrm{P}_{2} \mathrm{Y}_{12}$ antagonists. ${ }^{28,29}$

\section{The Platelet P2Y 1 Receptor in Thrombosis}

Although the $\mathrm{P}_{2} \mathrm{Y}_{1}$ receptor plays only a modest role in platelet activation, it plays a central role in experimental arterial thrombosis. This was shown using $\mathrm{P}_{2} \mathrm{Y}_{1}{ }^{-1-}$ mice in various models including systemic thromboembolism either induced by infusion of a mixture of collagen and adrenaline $e^{30,31}$ or tissue factor, ${ }^{32}$ or localised thrombosis after ferric chloride- or laser-induced injury of mesenteric arteries. ${ }^{33}$ Among selective $\mathrm{P}_{1} \mathrm{Y}_{1}$ receptor antagonists, MRS2500 has so far the highest affinity for $\mathrm{P}_{2} \mathrm{Y}_{1}$ and is able to inhibit thrombosis in treated 
animals. ${ }^{34}$ However, the limited bioavailability of the compound prevents its use in long-term treatment, pointing to the need of developing novel $\mathrm{P}_{2} \mathrm{Y}_{1}$ receptor antagonists with an improved pharmacokinetic profile. The resolution of the X-ray crystal structure of the $\mathrm{P}_{2} \mathrm{Y}_{1}$ receptor ${ }^{35}$ should open up new possibilities in this field. Of note, inhibition of the $\mathrm{P}_{2} \mathrm{Y}_{1}$ receptor results in a moderate prolongation of the bleeding time in mice, which is a definite safety advantage over inhibition of the $\mathrm{P}_{2} \mathrm{Y}_{12}$ receptor. However, so far, no candidate drug has really emerged from any pharmaceutical company involved in antithrombotic drug development.

\section{The Platelet $\mathbf{P 2 X}_{\mathbf{1}}$ Receptor in Thrombosis}

The generation of $\mathrm{P}_{2} \mathrm{X}_{1}{ }^{-1-}$ mice helped to reveal the important role of this receptor in arterial thrombosis. $\mathrm{P}_{2} \mathrm{X}_{1}{ }^{-1-}$ mice display resistance to systemic thromboembolism induced by injection of a mixture of collagen and adrenaline and to localised arterial thrombosis triggered by laser-induced injury of mesenteric arteries. ${ }^{24}$ These mice display also resistance to tissue factor-induced systemic thromboembolism, i.e., in a thrombin-dependent system (unpublished data). Interestingly, $\mathrm{P} 2 \mathrm{X}_{1}{ }^{-1-}$ mice have no increase in their bleeding time compared with wild-type animals, indicating that they display normal haemostasis. ${ }^{24}$ This receptor is therefore a potential new target for safe antiplatelet agents. However, due to the limited bioavailability and selectivity of currently existing $\mathrm{P}_{2} \mathrm{X}_{1}$ antagonists, the development of novel selective $\mathrm{P}_{2} \mathrm{X}_{1}$ antagonists is warranted for the preclinical evaluation of this receptor as a target for novel antiplatelet agents.

\section{The Platelet P2 Receptors in Inflammation}

Platelets play an important role in modulating inflammatory responses through the release of inflammatory mediators or compounds with trophic activity and exposure of P-selectin, CD40 and CD40 ligand (CD40L). These molecules allow interaction of platelets with leukocytes and their subsequent activation with the release of a range of inflammatory cytokines and exposure of tissue factor. ${ }^{36}$ Therefore, in addition to acting as antithrombotic drugs, antagonists and inhibitors of the platelet P2 receptors have anti-inflammatory effects, which might be relevant to various diseases such as atherosclerosis, restenosis, endotoxaemia and sepsis, or allergic asthma. In addition, besides platelets, $\mathrm{P}_{2} \mathrm{Y}_{1}, \mathrm{P}_{2} \mathrm{Y}_{12}$ and $\mathrm{P} 2 \mathrm{X}_{1}$ receptors, expressed by cells of the immune system and by vascular cells, are also directly involved in the modulation of inflammation and in immune responses during thrombus formation, independently of platelet-related processes ${ }^{37}$ ( - Table 1 ).

\section{The $\mathbf{P 2 Y}_{12}$ Receptor}

Studies in mice or patients receiving clopidogrel have highlighted the contribution of the platelet $\mathrm{P}_{2} \mathrm{Y}_{12}$ receptor to P-selectin and CD40L exposure, formation of platelet-leukocyte aggregates, tissue factor exposure and release of various inflammatory mediators (tumour necrosis factor- $\alpha$, C-reactive protein). ${ }^{38}$ These inflammatory events might be relevant for the role played by the platelet $\mathrm{P}_{2} \mathrm{Y}_{12}$ receptor in restenosis, ${ }^{39}$ atherosclerosis $^{40,41}$ and transplant atherosclerosis. An additional contribution from the $\mathrm{P}_{2} \mathrm{Y}_{12}$ receptor of VSMCs and leukocytes, including DCs, possibly through $\mathrm{P}_{2} \mathrm{Y}_{12}$-dependent migration properties has been suggested. ${ }^{42,43}$ In the context of allergic asthma, in which platelet activation is required for the recruitment of inflammatory cells to the lungs and remodelling of the airway wall, divergent results have been reported concerning the role of the platelet $\mathrm{P}_{2} \mathrm{Y}_{12}$ receptor. The proasthmatic action of leukotriene LTE4 in mice could require the $\mathrm{P}_{2} \mathrm{Y}_{12}$ receptor through a mechanism yet to be identified. ${ }^{44}$ Further evidence of the involvement of the $\mathrm{P}_{2} \mathrm{Y}_{12}$ platelet

Table 1 Role of the $\mathrm{P}_{2} \mathrm{Y}_{1}, \mathrm{P}_{2} \mathrm{Y}_{12}, \mathrm{P} 2 \mathrm{X}_{1}$ and $\mathrm{P}_{2} \mathrm{Y}_{14}$ receptors in inflammatory processes and related diseases

\begin{tabular}{|c|c|c|c|}
\hline Inflammatory disease & & Cell type & Reference \\
\hline \multirow[t]{3}{*}{ Atherosclerosis } & $\mathrm{P}_{2} \mathrm{Y}_{12}$ & Platelets & Li et al $(2012)^{40} ;$ West et al $(2014)^{41}$ \\
\hline & & VSMCs & Li et al $(2012)^{40} ;$ West et al $(2014)^{41}$ \\
\hline & $\mathrm{P} 2 \mathrm{Y}_{1}$ & Endothelial cells & Hechler et al $(2008)^{51}$; Zerr et al $(2011)^{50}$ \\
\hline Restenosis & $\mathrm{P} 2 \mathrm{Y}_{12}$ & Platelets & Evans et al $(2009)^{31}$ \\
\hline \multirow[t]{2}{*}{ Transplant atherosclerosis } & $\mathrm{P}_{2} \mathrm{Y}_{12}$ & VSMCs & Abele et al $(2009)^{42}$; Harada et al $(2011)^{43}$ \\
\hline & & Leukocytes & Abele et al $(2009)^{42}$; Harada et al $(2011)^{43}$ \\
\hline \multirow[t]{2}{*}{ Intimal hyperplasia } & $\mathrm{P} 2 \mathrm{Y}_{1}$ & Platelets & Liu et al $(2015)^{52}$ \\
\hline & & Macrophages & Liu et al $(2015)^{52}$; Marques-da-Silva et al $(2011)^{53}$ \\
\hline \multirow[t]{3}{*}{ Endotoxaemia/sepsis } & $\mathrm{P}_{2} \mathrm{Y}_{12}$ & Platelets & Hagiwara et al $(2011)^{47}$; Liverani et al $(2016)^{48}$ \\
\hline & $\mathrm{P} 2 \mathrm{X}_{1}$ & Neutrophils & Lecut et al $(2012)^{56}$; Maître et al $(2015)^{57}$ \\
\hline & $\mathrm{P}_{2} \mathrm{Y}_{14}$ & Platelets & Sesma et al $(2016)^{59}$; Amison et al $(2017)^{60}$ \\
\hline Transfusion-related acute lung injury & $\mathrm{P} 2 \mathrm{X}_{1}$ & Monocytes/macrophages & El Mdawar et al $(2019)^{58}$ \\
\hline \multirow[t]{2}{*}{ Asthma } & $\mathrm{P}_{2} \mathrm{Y}_{12}$ & Platelets & Paruchuri et al $(2009)^{44}$; Cattaneo $(2015)^{45}$ \\
\hline & $\mathrm{P} 2 \mathrm{Y}_{1}$ & Platelets & Amison et al $(2015)^{46}$ \\
\hline
\end{tabular}

Abbreviation: VSMCs, vascular smooth muscle cells. 
receptor in asthma is provided by clinical observations of a large family-based asthma cohort, in which $\mathrm{P}_{2} \mathrm{Y}_{12}$ receptor variants were associated with altered lung function, while prasugrel tended to decrease the bronchial hyper-reactivity to mannitol in patients with allergic asthma. ${ }^{45}$ In contrast, Amison et al reported that the platelet $\mathrm{P} \mathrm{Y}_{12}$ receptor is dispensable in allergic inflammation in ovalbumin-challenged mice. ${ }^{46}$ The platelet $\mathrm{P}^{2} \mathrm{Y}_{12}$ receptor contributes also to the deleterious pro-inflammatory role of platelets in enhancing the pulmonary neutrophil infiltration and exacerbating tissue damage during lipopolysaccharide (LPS)-induced endotoxemia. ${ }^{47}$ Concerning the potential role of the platelet $\mathrm{P} \mathrm{Y}_{12}$ receptor in sepsis, here also, contradictory results have been reported. On the one hand, Liverani et al reported a central role of $\mathrm{P}_{2} \mathrm{Y}_{12},{ }^{48}$ while on the other hand our group reported that inhibition of the $\mathrm{P}_{12} \mathrm{Y}_{12}$ receptor with clopidogrel or platelet

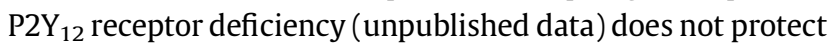
mice from septic shock. Further studies are required to clarify all these discrepancies, most probably related to differences in models, administered drugs and/or the use of receptor-deficient mice, to elucidate the contribution of the $\mathrm{P}_{2} \mathrm{Y}_{12}$ receptor in various settings. The perspective could be to extend the use of $\mathrm{P}_{2} \mathrm{Y}_{12}$ targeting drugs beyond their current indications.

\section{The P2Y Receptor}

The platelet $\mathrm{P} 2 \mathrm{Y}_{1}$ receptor contributes to platelet P-selectin exposure and the formation of platelet-leukocyte conjugates resulting in leukocyte activation and tissue factor exposure. ${ }^{49}$ These $\mathrm{P}_{2} \mathrm{Y}_{1}$ receptor-mediated events might be relevant for the platelet-dependent recruitment of leukocytes to the lung tissue in the case of inflammation of the airways in allergic mice, ${ }^{46}$ although the contribution of the $\mathrm{P}_{2} \mathrm{Y}_{1}$ receptors from other cell types such as leukocytes or endothelial cells cannot be excluded. Indeed, in an experimental model of acute vascular inflammation, the endothelial $\mathrm{P}_{2} \mathrm{Y}_{1}$ receptor plays an important role in the upregulation of adhesion molecules (P-selectin, VCAM-1, ICAM- 1 and the recruitment of leukocytes at the vascular wall). ${ }^{50}$ The endothelial $\mathrm{P}_{2} \mathrm{Y}_{1}$ receptor also contributes to development of atherosclerosis, a chronic inflammatory process, in $\mathrm{ApoE}^{-1-}$ mice. ${ }^{51}$ The $\mathrm{P}_{2} \mathrm{Y}_{1}$ receptor has also been shown to be present on VSMCs, where it contributes to their proliferation and migration in vitro. This could be relevant for the intimal hyperplasia observed in a vein graft model in mice. ${ }^{52}$ In this case, a contribution from the P2Y receptors present on platelets and macrophages cannot be excluded. Macrophages would indeed appear to be required, as their depletion abrogated hyperplasia, ${ }^{52}$ while data indicated a role of the $\mathrm{P}_{2} \mathrm{Y}_{1}$ receptor in the phagocytic and migration activity of macrophages ${ }^{53}$ Altogether, these pieces of evidence suggest that the $\mathrm{P}_{2} \mathrm{Y}_{1}$ receptor could represent an attractive and original target for drugs with multiple sites of action, to treat atherothrombosis and, possibly, other inflammatory diseases. Again, the main problem is the lack of good drug candidates to further evaluate this receptor as a potential target for new drug candidates.

\section{The P2X 1 Receptor}

The platelet $\mathrm{P}_{2} \mathrm{X}_{1}$ receptor, along with the neutrophil $\mathrm{P} 2 \mathrm{X}_{1}$ receptor, may contribute to thrombus formation in a context of inflammation as highlighted in a specific model of neutrophil-dependent thrombosis of cremasteric arterioles triggered by laser injury. The neutrophil $\mathrm{P}_{2} \mathrm{X}_{1}$ receptor appeared essential for their recruitment at the site of vessel injury and subsequent fibrin production and thrombus formation. ${ }^{54}$ Very recently, a role of the platelet $\mathrm{P}_{2} \mathrm{X}_{1}$ receptor in the enhancement of FcrRIIa-induced $\mathrm{Ca}^{2+}$ increases and functional responses has been reported, which may be relevant for in vivo platelet-dependent immune responses..$^{55}$ The $\mathrm{P} 2 \mathrm{X}_{1}$ receptor from neutrophils plays also an important part in facilitating the neutrophil chemotaxis induced by various chemoattractants, possibly by favouring contraction and retraction of the trailing uropod. ${ }^{56}$ Accordingly, the P2X receptor from neutrophil, or from monocyte/macrophage, displays an important role in inflammatory diseases leading to organ damage, such as endotoxemia ${ }^{57}$ or transfusionrelated acute lung injury (TRALI). ${ }^{58}$ Thus, similarly to P2Y ${ }_{1}$, the $\mathrm{P} 2 \mathrm{X}_{1}$ receptor could constitute an attractive target for new therapeutics not only in thrombosis but also in inflammatory processes. Here also, the lack of potent and selective compounds with favourable bioavailability hampers the further evaluation of the potential of this receptor as a valuable target for new drugs.

\section{The P2Y $_{14}$ Receptor}

As already mentioned, platelets express the $\mathrm{P}_{2} \mathrm{Y}_{14}$ receptor but its function in platelet physiology is unknown and no modulation of thrombosis has been detected using $\mathrm{P}_{2} \mathrm{Y}_{14}{ }^{-1-}$ mice in various models of arterial thrombosis (unpublished data). However, using $\mathrm{P}^{2} \mathrm{Y}_{14}$ antagonists, separate studies have reported a role of this receptor in leukocyte recruitment in vitro and in vivo. Pulmonary neutrophil recruitment induced by intranasal LPS administration and LPS-induced thrombocytopenia were inhibited in mice administered with a $\mathrm{P}_{2} \mathrm{Y}_{14}$ antagonist. ${ }^{59,60}$ In addition, the stimulation of platelets with selective P2Y ${ }_{14}$ agonists (UDP-glucose, MRS2690) resulted in significant platelet-dependent neutrophil chemotaxis toward macrophage-derived chemokine (CCL22), in vitro. Similarly, the $\mathrm{P}_{2} \mathrm{Y}_{1}$ receptor seems to play a specific role in plateletdependent neutrophil chemotaxis. ${ }^{60}$

\section{Conclusions}

Each of the platelet receptors for extracellular adenine nucleotides plays a specific role in platelet functions and arterial thrombosis. Each of these receptors also contributes to the development of various processes related to acute or chronic inflammation. The respective contributions of the platelet receptors and those of other cell types are not yet well unravelled. Undoubtedly, the generation of mice with a specific tissue deletion of these $\mathrm{P} 2$ receptor subtypes will help to define their specific functions under various pathological conditions. In addition, the development of novel P2X and 
$\mathrm{P}_{1} \mathrm{Y}_{1}$ receptor antagonists with an improved pharmacokinetic profile should clearly open up new possibilities in this field. The perspective is that these $\mathrm{P} 2$ receptors could also represent potential therapeutic targets for the treatment of inflammatory diseases.

\section{Disclosures}

None.

\section{Conflict of Interest}

The authors declare that they have no conflict of interest.

\section{References}

1 Gaarder A, Jonsen J, Laland S, Hellem A, Owren PA. Adenosine diphosphate in red cells as a factor in the adhesiveness of human blood platelets. Nature 1961;192:531-532

2 Born GVR. Aggregation of blood platelets by adenosine diphosphate and its reversal. Nature 1962;194:927-929

3 Maffrand JP, Bernat A, Delebassée D, Defreyn G, Cazenave JP, Gordon JL. ADP plays a key role in thrombogenesis in rats. Thromb Haemost 1988;59(02):225-230

4 Cattaneo M, Canciani MT, Lecchi A, et al. Released adenosine diphosphate stabilizes thrombin-induced human platelet aggregates. Blood 1990;75(05):1081-1086

5 Dovlatova N, Wijeyeratne YD, Fox SC, et al. Detection of P2Y(14) protein in platelets and investigation of the role of $\mathrm{P} 2 \mathrm{Y}(14)$ in platelet function in comparison with the $\mathrm{EP}(3)$ receptor. Thromb Haemost 2008;100(02):261-270

6 Hechler B, Léon C, Vial C, et al. The P2Y1 receptor is necessary for adenosine 5'-diphosphate-induced platelet aggregation. Blood 1998;92(01):152-159

7 Léon C, Hechler B, Vial C, Leray C, Cazenave JP, Gachet C. The P2Y1 receptor is an ADP receptor antagonized by ATP and expressed in platelets and megakaryoblastic cells. FEBS Lett 1997;403(01):26-30

8 Waldo GL, Harden TK. Agonist binding and Gq-stimulating activities of the purified human P2Y1 receptor. Mol Pharmacol 2004;65 (02):426-436

9 Crittenden JR, Bergmeier W, Zhang Y, et al. CalDAG-GEFI integrates signaling for platelet aggregation and thrombus formation. Nat Med 2004;10(09):982-986

10 Gachet C. Regulation of platelet functions by P2 receptors. Annu Rev Pharmacol Toxicol 2006;46:277-300

11 Hollopeter G, Jantzen HM, Vincent D, et al. Identification of the platelet ADP receptor targeted by antithrombotic drugs. Nature 2001;409(6817):202-207

12 Zhang FL, Luo L, Gustafson E, et al. ADP is the cognate ligand for the orphan G protein-coupled receptor SP1999. J Biol Chem 2001;276 (11):8608-8615

13 Hechler B, Eckly A, Ohlmann P, Cazenave JP, Gachet C. The P2Y1 receptor, necessary but not sufficient to support full ADP-induced platelet aggregation, is not the target of the drug clopidogrel. Br J Haematol 1998;103(03):858-866

14 Trumel C, Payrastre B, Plantavid M, et al. A key role of adenosine diphosphate in the irreversible platelet aggregation induced by the PAR1-activating peptide through the late activation of phosphoinositide 3-kinase. Blood 1999;94(12):4156-4165

15 Kauffenstein G, Hechler B, Cazenave JP, Gachet C. Adenine triphosphate nucleotides are antagonists at the P2Y receptor. J Thromb Haemost 2004;2(11):1980-1988

16 Cattaneo $\mathrm{M}$. The platelet $\mathrm{P}_{2} \mathrm{Y}_{12}$ receptor for adenosine diphosphate: congenital and drug-induced defects. Blood 2011;117(07): 2102-2112

17 Gremmel T, Michelson AD, Frelinger AL III, Bhatt DL. Novel aspects of antiplatelet therapy in cardiovascular disease. Res Pract Thromb Haemost 2018;2(03):439-449
18 Gachet C.P2Y(12) receptors in platelets and other hematopoietic and non-hematopoietic cells. Purinergic Signal 2012;8(03):609-619

19 Hechler B, Gachet C. Purinergic receptors in thrombosis and inflammation. Arterioscler Thromb Vasc Biol 2015;35(11):2307-2315

20 Hao Y, Wang L, Chen $\mathrm{H}$, et al. Targetable purinergic receptors P2Y12 and A2b antagonistically regulate bladder function. JCI Insight 2019;4(16):122112

21 Gratacap MP, Guillermet-Guibert J, Martin V, et al. Regulation and roles of PI3K $\beta$, a major actor in platelet signaling and functions. Adv Enzyme Regul 2011;51(01):106-116

22 Stefanini L, Paul DS, Robledo RF, et al. RASA3 is a critical inhibitor of RAP1-dependent platelet activation. J Clin Invest 2015;125 (04):1419-1432

23 Lecchi A, Femia EA, Paoletta S, et al. Inherited dysfunctional platelet $\mathrm{P}_{2} \mathrm{Y}_{12}$ receptor mutations associated with bleeding disorders. Hamostaseologie 2016;36(04):279-283

24 Hechler B, Lenain N, Marchese P, et al. A role of the fast ATP-gated $\mathrm{P} 2 \times 1$ cation channel in thrombosis of small arteries in vivo. J Exp Med 2003;198(04):661-667

25 Cattaneo M. The P2 receptors and congenital platelet function defects. Semin Thromb Hemost 2005;31(02):168-173

26 Oury C, Toth-Zsamboki E, Van Geet C, et al. A natural dominant negative $\mathrm{P} 2 \times 1$ receptor due to deletion of a single amino acid residue. J Biol Chem 2000;275(30):22611-22614

27 Gachet C. Antiplatelet drugs: which targets for which treatments? J Thromb Haemost 2015;13(Suppl 1):S313-S322

28 Zhang J, Zhang K, Gao ZG, et al. Agonist-bound structure of the human P2Y12 receptor. Nature 2014;509(7498):119-122

29 Zhang K, Zhang J, Gao ZG, et al. Structure of the human P2Y12 receptor in complex with an antithrombotic drug. Nature 2014; 509(7498):115-118

30 Fabre JE, Nguyen M, Latour A, et al. Decreased platelet aggregation, increased bleeding time and resistance to thromboembolism in P2Y1-deficient mice. Nat Med 1999;5(10):1199-1202

31 Léon C, Hechler B, Freund M, et al. Defective platelet aggregation and increased resistance to thrombosis in purinergic P2Y(1) receptor-null mice. J Clin Invest 1999;104(12):1731-1737

32 Léon C, Freund M, Ravanat C, Baurand A, Cazenave JP, Gachet C. Key role of the P2Y(1) receptor in tissue factor-induced thrombindependent acute thromboembolism: studies in P2Y(1)-knockout mice and mice treated with a P2Y(1) antagonist. Circulation 2001; 103(05):718-723

33 Lenain N, Freund M, Léon C, Cazenave JP, Gachet C. Inhibition of localized thrombosis in P2Y1-deficient mice and rodents treated with MRS2179, a P2Y1 receptor antagonist. J Thromb Haemost 2003;1(06):1144-1149

34 Hechler B, Nonne C, Roh EJ, et al. MRS2500 [2-iodo-N6-methyl(N)-methanocarba-2'-deoxyadenosine-3',5'-bisphosphate], a potent, selective, and stable antagonist of the platelet P2Y1 receptor with strong antithrombotic activity in mice.J Pharmacol Exp Ther 2006;316(02):556-563

35 Zhang D, Gao ZG, Zhang K, et al. Two disparate ligand-binding sites in the human P2Y1 receptor. Nature 2015;520(7547):317-321

36 Morrell CN, Aggrey AA, Chapman LM, Modjeski KL. Emerging roles for platelets as immune and inflammatory cells. Blood 2014;123 (18):2759-2767

37 Idzko M, Ferrari D, Eltzschig HK. Nucleotide signalling during inflammation. Nature 2014;509(7500):310-317

38 Steinhubl SR, Badimon JJ, Bhatt DL, Herbert JM, Lüscher TF. Clinical evidence for anti-inflammatory effects of antiplatelet therapy in patients with atherothrombotic disease. Vasc Med 2007;12(02):113-122

39 Evans DJ, Jackman LE, Chamberlain J, et al. Platelet P2Y(12) receptor influences the vessel wall response to arterial injury and thrombosis. Circulation 2009;119(01):116-122

40 Li D, Wang Y, Zhang L, et al. Roles of purinergic receptor P2Y, G proteincoupled 12 in the development of atherosclerosis in apolipoprotein Edeficient mice. Arterioscler Thromb Vasc Biol 2012;32(08):e81-e89 
41 West LE, Steiner T, Judge HM, Francis SE, Storey RF. Vessel wall, not platelet, P2Y12 potentiates early atherogenesis. Cardiovasc Res 2014;102(03):429-435

42 Abele S, Spriewald BM, Ramsperger-Gleixner M, et al. Attenuation of transplant arteriosclerosis with clopidogrel is associated with a reduction of infiltrating dendritic cells and macrophages in murine aortic allografts. Transplantation 2009;87(02):207-216

43 Harada K, Matsumoto Y, Umemura K. Adenosine diphosphate receptor P2Y12-mediated migration of host smooth muscle-like cells and leukocytes in the development of transplant arteriosclerosis. Transplantation 2011;92(02):148-154

44 Paruchuri S, Tashimo H, Feng C, et al. Leukotriene E4-induced pulmonary inflammation is mediated by the P2Y12 receptor. J Exp Med 2009;206(11):2543-2555

45 Cattaneo M. The platelet P2 receptors in inflammation. Hamostaseologie 2015;35(03):262-266

46 Amison RT, Momi S, Morris A, et al. RhoA signaling through platelet $\mathrm{P}_{2} \mathrm{Y}_{1}$ receptor controls leukocyte recruitment in allergic mice. J Allergy Clin Immunol 2015;135(02):528-538

47 Hagiwara S, Iwasaka H, Hasegawa A, et al. Adenosine diphosphate receptor antagonist clopidogrel sulfate attenuates LPS-induced systemic inflammation in a rat model. Shock 2011;35(03):289-292

48 Liverani E, Rico MC, Tsygankov AY, Kilpatrick LE, Kunapuli SP. P2Y12 receptor modulates sepsis-induced inflammation. Arterioscler Thromb Vasc Biol 2016;36(05):961-971

49 Léon C, Ravanat C, Freund M, Cazenave JP, Gachet C. Differential involvement of the P2Y1 and P2Y12 receptors in platelet procoagulant activity. Arterioscler Thromb Vasc Biol 2003;23(10): 1941-1947

50 Zerr M, Hechler B, Freund M, et al. Major contribution of the $\mathrm{P}_{2} \mathrm{Y}_{1}$ receptor in purinergic regulation of TNF $\alpha$-induced vascular inflammation. Circulation 2011;123(21):2404-2413

51 Hechler B, Freund M, Ravanat C, Magnenat S, Cazenave JP, Gachet C. Reduced atherosclerotic lesions in P2Y1/apolipoprotein E double-knockout mice: the contribution of non-hematopoieticderived P2Y1 receptors. Circulation 2008;118(07):754-763

52 Liu R, Ma S, Lu Z, Shen H, Sun L, Wei M. The ADP antagonist MRS2179 regulates the phenotype of smooth muscle cells to limit intimal hyperplasia. Cardiovasc Drugs Ther 2015;29(01):23-29

53 Marques-da-Silva C, Burnstock G, Ojcius DM, Coutinho-Silva R. Purinergic receptor agonists modulate phagocytosis and clearance of apoptotic cells in macrophages. Immunobiology 2011;216 $(1-2): 1-11$

54 Darbousset R, Delierneux C, Mezouar S, et al. P2 $\times 1$ expressed on polymorphonuclear neutrophils and platelets is required for thrombosis in mice. Blood 2014;124(16):2575-2585

55 Ilkan Z, Watson S, Watson SP, Mahaut-Smith MP. P2 $\times 1$ receptors amplify FcrRIla-induced $\mathrm{Ca} 2+$ increases and functional responses in human platelets. Thromb Haemost 2018;118(02): 369-380

56 Lecut C, Faccinetto C, Delierneux C, et al. ATP-gated P2 $\times 1$ ion channels protect against endotoxemia by dampening neutrophil activation. J Thromb Haemost 2012;10(03):453-465

57 Maître B, Magnenat S, Heim V, et al. The P2 $\times 1$ receptor is required for neutrophil extravasation during lipopolysaccharide-induced lethal endotoxemia in mice. J Immunol 2015;194 (02):739-749

58 El Mdawar MB, Maître B, Magnenat S, Gachet C, Hechler B, de la Salle $\mathrm{H}$. The ATP-gated $\mathrm{P}_{2} \mathrm{X}_{1}$ ion channel contributes to the severity of antibody-mediated transfusion-related acute lung injury in mice. Sci Rep 2019;9(01):5159

59 Sesma JI, Weitzer CD, Livraghi-Butrico A, et al. UDP-glucose promotes neutrophil recruitment in the lung. Purinergic Signal 2016;12(04):627-635

60 Amison RT, Arnold S, O'Shaughnessy BG, et al. Lipopolysaccharide (LPS) induced pulmonary neutrophil recruitment and platelet activation is mediated via the $\mathrm{P}_{2} \mathrm{Y}_{1}$ and $\mathrm{P}_{2} \mathrm{Y}_{14}$ receptors in mice. Pulm Pharmacol Ther 2017;45:62-68 